\title{
EL OJO EN
}

PALINURO DE

MÉXICO: LA

IMAGINACIÓN

GROTESCA*

Lilia García Peña ${ }^{* *}$

Teer Palinuro de México significa entrar en un laberinto de imágenes visuales; sumergirse, página a página, en el cauce complejo y gozoso de lo óptico. Desde los primeros capítulos la novela se llena de formas y volúmenes, de colores que encarnan en vientos negros, en lirios, camelias y heliotropos; en las vísceras rosadas o azules del cuerpo humano.

Se privilegia la mirada, pero ésta no es inocente -como ninguna lo es. La visión humanà es una práctica cultural e histórica, y así en Palinuro de México se afirma una "visión particular del mundo": ${ }^{1}$ una visión caleidoscópica de la realidad. Recordemos que Palinuro y Estefanía viven su niñez en la mansión porfiriana de los abuelos convertida en casa de huéspedes, donde les parecía asombrosa "la lámpara imperial del comedor que siempre estaba en un vértice de transformarse en caleidoscopio" (18); y que años más tarde, Palinuro deseará "ver las cosas a través de un caleidoscopio que cada vez que el mundo diera una vuelta, dibujara una fábula distinta..." (285)

* Actualmente la autora lleva a cabo una investigación más amplia sobre Palinuro de México como tesis doctoral.

** El Colegio de México.

${ }^{1}$ Fernando del Paso, Palinuro de México, 1980, México, Joaquín Mortiz, p. 180 [Alfaguara, Madrid, 1977]. De ahora en adelante citaré indicando solamente el número de página entre paréntesis. 
El ojo de Palinuro experimenta como un caleidoscopio con luces, espejos y colores; deforma lo que mira y produce una percepción móvil y fragmentada de la realidad: una percepción "descentrada". Justamente, la visualización deformada de la realidad es una de las razones por la cuales se puede decir que esta novela entronca con la tradición grotesca, ya que ésta es característica esencial de tal tipo de representación; estética de lo grotesco es, en gran medida, la estética de la deformidad. ${ }^{2}$ Por otra parte, no parece raro que una novela grotesca sea poderosamente visual, si se piensa que el término nació intrinsecamente ligado a las artes visuales. ${ }^{3}$

En la novela, esta relación fundamental entre lo grotesco y lo visual se muestra de manera destacada en el capítulo "El ojo universal", en donde el narrador-doble, al rasurar a Palinuro para librarlo de las ladillas, descubre en sus partes bajas el ojo de vidrio del general que se había tragado durante la "borrachera" del día anterior. Este pasaje, que recuerda el tono grotesco de "Las gracias y desgracias del ojo del culo" de Quevedo, ${ }^{4}$ nos conduce a importantes claves, ya que el ojo de vidrio en el ano de Palinuro se asemeja al ojo único y sin párpados, que es símbolo de la esencia y el conocimiento divinos; ${ }^{5}$ a la vez que a un ojo-ventana que sugiere abertura y regocijada libertad. ${ }^{6}$

El órgano epistemológico por excelencia se ata aquí al excremento y también a la sangre, cuando el narrador-doble corta por descuido la piel

${ }^{2}$ Cf. Mijaíl Bajtín, La cultura popular en la Edad Media y en el Renacimiento. El contexto de François Rabelais, $3^{\text {a }}$ ed., trad. Julio Forcat y César Conroy, 1990, México, Alianza, p. 44 [1 1 . ed. en ruso 1965] y Philip Thomson, The grotesque, 1972, Londres, Methuen, p. 20.

${ }^{3}$ Grotesco (del italiano grotta, gruta) se restringe originalmente a un tipo de pintura ornamental descubierta a fines del siglo XV en unas excavaciones en Roma. Los hallazgos del llamado palacio de Tito se caracterizan por el juego fantástico y libre de formas, humanas, animales y vegetales. Cf. Frances Barasch, The grotesque: a study in meanings, 1971, La Haya, Moutton, p. 18s.

${ }^{4}$ Este texto es, además, explícitamente citado en la novela, p. 103.

${ }^{5}$ Cf. Jean Chevalier y A Gheerbrant, Diccionario de los símbolos, trad. Manuel Silvar y Arturo Rodríguez, 1986, Barcelona, Herder, p. $7711^{19}$ ed. en francés 1969].

${ }^{6}$ Cf. Juan Eduardo Cirlot, El ojo en la mitología. Su simbolismo, 1992, Madrid, Ediciones Libertarias, p. 72. 
de Palinuro: triunfa la orientación hacia lo bajo que es característico de las formas del realismo grotesco. ${ }^{7}$

Por otra parte, el ojo heterotópico de Palinuro nos hace pensar en una de las importantes fuentes del texto: el surrealismo, ya que la liberación de fuerzas irracionales y la creación de imágenes heterogéneas conlleva el desplazamiento del objeto. Podemos decir, guardando todas las proporciones, que volver heterotópico un objeto, es un acto surrealista. 8

Destaca en la novela la imagen del ojo abierto como símbolo de apertura al conocimiento, podemos mencionar, por ejemplo, la imagen repetida de "los ojos inmensamente abiertos" de Estefanía $(21,22,69)$.

El ojo en Palinuro de México es vía de conocimiento de lo sensible a través del descubrimiento del amor y de eros; son los "ojos verdes y resbaladizos" (17) de Lucrecia, la madre de Estefanía, los que seducen a Esteban; y son los ojos de Estefanía los que un día, mientras hacen el amor, se inundan de semen de Palinuro, y miran el mundo a través del "licor turbio... espeso y translúcido..." (78). Es también a través de los ojos que se conoce el mundo en la infancia, cuando "Palinuro y Estefanía se sentaban en las tardes, con la tía Luisa, a descubrir rostros en el claroscuro de los nomeolvides" (18).

Para reflexionar sobre la postura teórica que sustenta Palinuro de México acerca del ojo como instrumento epistemológico, es pertinente revisar la nutrida intertextualidad que en este orden encierra la novela.

Por una parte, Palinuro cita un gran número de ojos "célebres provenientes de la mitología, la pintura y la literatura, de los cuales podemos destacar, por su valor simbólico con relación al problema del conocimiento y sus límites, el ojo único de Polifemo (102) que indica una naturaleza infrahumana: como si el concepto fuera que el segundo ojo humano corresponde a la visión intelectual y el primero a la meramente espacial; ${ }^{9}$ o los cien ojos de Argos (104) que, por su dispersión e incapacidad para cerrarse simultáneamente, sugieren la idea de que el ser es absorbido por el mundo exterior. ${ }^{10}$

${ }^{7}$ Véase Bajtín, op. cit., p. 30.

${ }^{8}$ Cf. Cirlot, op. cit., p. 66. Se le llama heterotópico al ojo desplazado de su ubicación natural.

${ }_{9}^{9}$ Cirlot, op. cit., p. 46.

${ }^{10}$ Cf. Chevalier, op. cit., p. 771. 


\section{Lilia García Peña}

Sin embargo, creo que la referencias importantes a considerar en estas páginas no son tanto las que el texto enlista para poner de manifiesto la persistencia del símbolo. Por el momento, me resultan determinantes las referencias enunciadas a través de Walter, que creo pueden ser validadas como fundamentos filosóficos del texto en virtud de la relación de espejeo y duplicación que se establece entre este personaje, Palinuro y el narrador-doble, ejes indiscutibles de la novela.

Un intertexto que resulta muy interesante con respecto al ojo y lo epistemológico, es la mención de Santa Lucía: “jamás podremos tener nuestros ojos en las manos -dice Walter-como Santa Lucía y verlos con nuestros propios ojos" (511). Cuenta la leyenda que Santa Lucía, considerada guardiana de la visión, se castigó a sí misma, por la pasión que despertó en un hombre, sacándose los ojos; Dios complacido ante la automutilación se los restauró por un día y ella pudo contemplar sus ojos con sus propios ojos. ${ }^{11}$ Podemos decir que esta referencia alude en Palinuro de México a la conciencia de los límites del conocimiento, que en la novela se enraíza profundamente en lo óptico.

En otro momento del texto Walter, caminando por las calles de Londres, se pregunta por la objetividad de las imágenes:

Hice un anillo de humo con mi cigarrillo, mucho más humilde e imperfecto, y al verme alli, reflejado en el escaparate, imagen de una imagen como diría Plotino, Cratilo ante Cratilo sin saber quién era el Walter de carne y hueso y quién el de carne y vidrio ...(501)

En este fragmento del texto se cuestionan los límites entre la cosa y su imagen en la línea platónica del diálogo "Cratilo". 2 Pero, por otra parte, se exaltan los poderes del ojo, ya que ante la mención de Plotino, no puede dejar de pensarse en la concepción que este filósofo tuvo del ojo como fuente de luz, conocimiento y fecundidad; para Plotino, de acuerdo al planteamiento de las emanaciones del "uno", "el ojo nunca hubiera logrado ver el sol si no fuera porque, en cierto modo, él mismo es un sol". 13

${ }^{11}$ Véase Edward Gifford, The evil eye. Studies in the folklore of vision, 1958, New York, McMillan, p. 128.

${ }^{12} \mathrm{El}$ "Cratilo" se centra fundamentalmente en la problemática de los nombres y las cosas que designan, pero de acuerdo al pasaje que se cita en Palinuro es este aspecto, también mencionado en el diálogo, el que nos interesa.

${ }^{13}$ Cirlot, op. cit., p. 25. 
Walter valida como absolutamente verdadera la visión alucinante que tiene del mundo un loco, un drogado o un epiléptico; validando quizá, a la vez, la "imaginación" grotesca y surrealista de la propia novela. Se apoya para ello en Ockham, quien dijo que "Dios podría producir en un ser humano todas las condiciones físicas y psíquicas implicadas en el acto de ver un objeto, aunque ese objeto no existiera en la realidad exterior..." (180).

Por otra parte, en la voz del narrador-doble se cita la aserción de Berkeley según la cual "los objetos visibles están dentro de nuestra mente" (327). La referencia a Berkeley pone a la novela en una vía coincidente con una postura sostenida por el empirismo inglés, cuyos antecedentes eran ya perceptibles en Guillermo de Ockham y que afirma que todo conocimiento procede de la experiencia; para Berkeley, ser es ser percibido y fuera de la percepción nada existe.

De la misma forma, Walter reafirma que es la percepción visual la que da realidad al mundo, realidad que en la novela se abre a los límites vertiginosos de lo alucinante; "cada uno de nosotros es un Dios Siva que cuando Parvati le tapa los ojos se apaga el sol y se apaga el farol de la esquina..." (183).

Después de haber reflexionado acerca de la postura que se advierte en el texto con respecto al ojo como órgano epistemológico, veamos un aspecto muy importante en la organización visual de la novela que es el amplio espacio dedicado a la pintura.

Desde niño, Palinuro decide ser pintor, y en el cuarto de la plaza de Santo Domingo abandona definitivamente los libros de medicina entre lo bello y lo repulsivo, entre el placer y el terror; en ellos plasma las imágenes de una infinidad de modelos pictóricos, desde obras de Giotto hasta Modigliani, que somete a un proceso de deformación; los cuerpos de los cuadros originales son rasgados, desmembrados y abiertos para mostrar sus músculos y sus venas.

Las representaciones grotescas que Palinuro pinta en nombre del terror, “del terror que se apoderó de él cuando comenzó a comprender y aceptar que su cuerpo estaba destinado a repartirse por los anfiteatros [...] o simplemente a hacerse polvo..." (269), muy bien pueden ilustrar la función de lo grotesco que implica un intento de conjurar lo demoníaco en el mundo. ${ }^{14}$

${ }^{14} \mathrm{Cf}$. Wolfang Kayser, Lo grotesco. Su configuración en pintura y literatura, trad. Ilse M. de Brugger, 1964, Buenos Aires, Nova, p. 228 [1a. ed. en alemán 1957]. 


\section{Lilia García Peña}

Los pintores y pinturas citadas en Palinuro de México son tan numerosas como importantes, ya que van tendiendo redes y claves de significación. Los pintores referidos pueden agruparse en distintas categorías; los que se citan para comparar a Estefanía con sus imágenes; los que se refieren para destacar la representación de amantes; los que se aluden porque plasman representaciones de la muerte; los pintores mencionados por representar el cuerpo humano enfermo, lacerado o torturado; los que Palinuro copia para efectuar sus transformaciones; los que son imitados en el procedimiento de representar el cuerpo abierto y desgarrado; y finalmente, los que se citan para ejemplificar un color o una forma descrita en el texto.

Podemos decir que Fernando del Paso recoge en esta novela un inmenso corpus pictórico, efectuando una relectura de artistas y obras del pasado. En este descomunal recorrido por la historia de la pintura se advierte que el cuerpo pictórico intertextual fluye en la novela por las vías de dos cauces especialmente importantes: los cuadros que responden a una representación grotesca y la pintura de vanguardia, especialmente surrealista. ${ }^{15}$

En el cauce de la representación grotesca podemos mencionar "La envidia" de Giotto (493); los martirios de Dirk Bouts (67); los leprosos

12 de Hans Burgkmair (20); las criaturas inverosímiles de Lucas Cranach (125); las obras de Rafael (125), quien fue uno de los primeros que pintó a imitación de los motivos grotescos del palacio de Tito; las insólitas parejas mujer-muerte de Hans Baldung (500); el horror cómico de Holbein el Viejo (81); "La danza de los muertos" de Holbein de Basilea (20); "La matanza de los inocentes" de Tintoretto, con sus cuerpos en agitación convulsa (126); el mundo onírico de Peter Brueghel, el Viejo (20); las figuras delgadas y verticalizantes de El Greco $(83,498)$; las figuras contrahechas de Velázquez (125); "La lección de anatomía" de Rembrandt $(126,488)$; los cadáveres que pintó el maestro del tardío

${ }^{15}$ Es pertinente señalar que, por el momento, me he propuesto analizar estas dos tendencias que considero relevantes en el texto, de tal manera que los pintores mencionados en estas páginas no agotan el cúmulo de nombres citados en la novela. Asimismo, me he permitido dejar para otro trabajo la significación que implica la presencia de tres artistas mexicanos en la novela: José Guadalupe Posada, Diego Rivera y José Luis Cuevas. 
barroco español, Valdés Leal (488); el ojo escailofriante de "La visión de la plaza de España" de Francesco Trevisan (104); las alegorías precursoras del surrealismo de Hogarth (127); los apestados del romántico Gros (20), "La bella Rosina" de Wierz (72); y los dibujos satíricos de Daumier (500).

Es posible decir que de entre los pintores que se ubican, de una u otra forma dentro de la estética de lo grotesco, Palinuro de México destaca a dos de ellos: El Bosco y Goya, el primero a través de una cita repetida $(20,119,201,422)$; el segundo porque se recuerda una de sus obras más famosas y a la que se recurre más frecuentemente en la historia del arte, como una clave, para hablar de la pintura de tendencia grotesca: "El sueño de la razón produce monstruos" (423).

Las impresiones plásticas grotescas definen en la novela una atmósfera densa, quimérica y deformada. En virtud del complejo montaje de intertextualidad pictórica, los ojos del lector se colman de imágenes monstruosas y caprichosas apariciones, se sumergen en el espacio alucinado en que se tocan el horror y la risa.

No es necesario dar un salto brusco hacia la otra tendencia pictórica que fluye en las páginas de Palinuro, la vanguardia. De hecho, Kayser contempla la obra de varios vanguardistas en su estudio, si bien deja al paso del tiempo la resolución de saber si pertenecen o no al área de lo grotesco; Thomson, en cambio, decididamente pone en una sola línea a Bosch, Brueghel y a los surrealistas como fuentes interesantes de lo grotesco. ${ }^{16}$

Si bien los nombres de los pintores pre y vanguardistas están dispersos a lo largo de toda la novela - como en el caso de los grotescos- es posible establecer con sus nombres una clara y organizada relación, lo cual deja ver una intencionalidad autoral.

Se citan cuatro importantes precursores de la vanguardia, Odilon Redon (104), Gauguin (125), Van Gogh (119, 182, 512); y Munch (201, 498) nombres que refieren a la pintura de Fin-de-Siécle que, como señala Baumer, fue un tiempo de quitar máscaras, de tratar de ir más allá de la

${ }^{16}$ Véase Thomson, op. cit., p. 24.

${ }^{17} \mathrm{Cf}$. Franklin Baumer, El pensamiento europeo moderno. Continuidad y cambio en las ideas, 1600-1950, trad. Juan José Utrilla, 1985, México, FCE, p. 359 [1a. ed. en inglés 1977]. 
Lilia García Peña

fachada racional del hombre. ${ }^{17}$ También, es posible identificar artistas relacionados con el expresionismo: Chagall (202); Modigliani (126); Soutine $(119,249)$; y con el cubismo: Picasso (278, 488, 517); y Léger (125).

Las referencias a la pintura surrealista son muy amplias. Se mencionan algunas figuras que preceden o influyen el movimiento, como el ensamblaje "Dados; $1^{\circ} \mathrm{La}$ Cascada, $2^{\circ} \mathrm{El}$ gas de alumbrado" de Marcel Duchamp, mencionado en el texto como una de aquellas construcciones "que se ven con un solo ojo" (103); el prodigioso creador de la pintura metafísica Giorgio de Chirico de quien se cita el color de sus desolados cielos (641). Los pintores surrealistas citados son: Man Ray y su ojo aniquilador (104); el creador del collage surrealista Max Ernst (104); Escher (119), artista de difícil clasificación, pero que puede ser visto en el trasfondo del surrealismo, especialmente de Magritte; Hans Bellmer (201), el creador de "La poupée", muñeca hecha de escobas sometida a diversas mutilaciones y combinaciones, y después fotografiada; Salvador Dalí (104, 135); y Klossowski (201).

Sitio aparte merecen en la intertextualidad pictórica surrealista Magritte $(104,488)$ y Paul Delvaux (125), entre cuyas obras y nuestra novela se advierten fuertes semejanzas en cuanto a la impresión plástica del espacio y las figuras que lo llenan. ${ }^{18}$ Palinuro comparte con la pintura de 14 Magritte la sencillez aparente donde se funde la amenaza y la ensoñación enigmática; con Delvaux lo enlaza el montaje de lo real-irreal, el goce del cuerpo femenino y el erotismo tenso entre perversidad e inocencia, la confrontación y diálogo de Eros-Thanatos; y también, a través de los esqueletos delvauxianos, la ratificación de la "tradición nórdica de lo macabro barroco que se remonta al Bosco y a Brueghel". 19

Además de las referencias intertextuales surrealistas, encontramos en Palinuro una clara adhesión a la estética de este movimiento por medio de la reelaboración de la conocida frase de Lautréamont. Durante el viaje de Palinuro por las agencias de publicidad, un psicoanalista lo reprueba en los exámenes psicológicos; no puede comprenderlo -se

${ }^{18}$ Fernando del Paso da un indicio para captar la correlación de la obra de estos artistas con Palinuro, con respecto a lo surrealista en el texto. Cf. Jorge Ruffinelli, "Entrevista con Fernando del Paso", Vuelta, 1979, núm. 37, p. 47.

${ }^{19}$ Marc Rombaut, Paul Delvaux, trad. Carles Ferrer, 1990, Barcelona, Polígrafa, p. 17. 
señala en el texto- porque ese médico nunca había tenido ocasión de asistir al encuentro casual del paraguas del primo Walter con la máquina de coser de Estefanía sobre la mesa de operaciones en Palinuro" (222).

La postura estética-epistemológica de Palinuro entronca con los principios de la pintura surrealista que llenan sus páginas, en tanto que la presencia de un yo desdoblado y fragmentado supone la imposibilidad de una perspectiva integrada del mundo. Al escamotear el ojo o seccionarlo, el surrealismo da cuenta de una conciencia rasgada que ya no controla el mundo; de la misma forma que esta novela mira el mundo desde un ojo deformante y fragmentado.

En este sentido, es posible decir que la mutilación y fragmentación obsesiva del cuerpo humano en Palinuro y las imágenes insólitas se relacionan con la búsqueda surrealista del extrañamiento, y con "la más sólida manera de lograrlo que consiste en unir lo que es dispar (collage) o separar lo que está unido o es afín (mutilación). ${ }^{20}$

Las numerosas referencias pictóricas, por otra parte, son ventanas que abren una multiplicidad de espacios, lo cual resulta importante si se advierte que la novela se organiza espacialmente desplazando el eje temporal.

He dicho que lo espacial desplaza el tiempo en Palinuro, pero es necesaria una precisión: en realidad, la dimensión temporal se espacializa, es decir, la novela se sustenta sobre el principio de que el ser no es sino memoria (cf. 520) y lo narrado en sus páginas son imágenes de la memoria; recuerdos, pero recuerdos espacializados porque toda memoria se apoya en lugares e imágenes.

En ese sentido Palinuro, avasallado por una infinidad de recuerdos, se convierte en un "cazador de reflejos" (289) que sólo pueden ser atrapados en el espacio de la escritura, el tiempo sólo puede apresarse en tanto los recuerdos queden "escritos en su corazón y escritos en su memoria indeleble: escritos en su lengua y escritos en el viento" (290).

Los personajes se ubican espacialmente y se definen por las distancias que los separan y los unen; así también, viajan de uno a otro sitio: Walter va a Londres; Palinuro y Estefanía recuerdan intensamente el viaje

${ }^{20}$ Agustín Sánchez Vidal, "Extrañamiento e identidad de su majestad el yo al éxtasis de los objetos", en El surrealismo, Víctor García de la Concha (ed.), 1982, Madrid, Taurus, p. 66. 


\section{Lilia García Peña}

hecho durante su infancia a Veracruz; Palinuro viaja a las agencias de publicidad y a otras islas imaginarias.

El espacio de Palinuro siempre es un ámbito urbano: Walter deambula por las calles de Londres, la Tía Luisa por las de París, el tío Esteban por las de Nueva Orleans, y Palinuro recorre con Estefanía "las calles atesoradas del barrio donde [nacieron], y que se sabían a sí mismas de memoria: Jalapa, Orizaba, Río de Janeiro" (28).

Los espacios privilegiados son los lugares cerrados, como los museos que Walter visita febrilmente, la cạntina "La Española" donde acuden los amigos de Palinuro, y la casa de los abuelos. Pero el más importante de todos es el cuarto de la plaza de Santo Domingo donde viven Estefanía y Palinuro: el espacio del amor, del asombro y también de la escritura, ya que "desde la ventana que daba a la plaza se podían ver [...] las imprentas y papelerías de los portales, los escritorios públicos y azules de los evangelistas..." (354).

El ojo de Palinuro ejerce también su poder deformante sobre los espacios de la novela y los invierte:

[La tía Luisa y Jean Paul] un día visitaron La Tour du Merveilleux, que era, para asombro de la tía Luisa, una casa al revés: se entraba por el desván, y se subía después al tercer piso y luego al segundo, y al primero, y así hasta llegar a la planta baja y al sótano. Las alfombras y los muebles estaban clavados en los techos, las lámparas se levantaban en medio del piso como fuentes de cristal, y a través de las ventanas y gracias a un juego ingenioso de espejos y cristales, se veía todo París al revés (112).

El cuarto de la Plaza de Santo Domingo se estructura siguiendo un orden inverso al natural, es decir, primero Palinuro elige la fotografía de Estefanía, después mandan construir las paredes y objetos que le convinieran, así como un edificio y una ciudad, siempre de acuerdo a la fotografía predilecta de Palinuro. Los primos poseen además en su cuarto un agente de inversión del espacio que es un huevo de

${ }^{21}$ El huevo al que alude la novela es la obra del escultor cubista Brancusi, "El principio del mundo", que posee efectivamente esta forma. 


\section{EL OJO EN PALINURO}

cristal diseñado — según Palinuro- por Brancusi, especialmente para ello: ${ }^{21}$

Y la mejor prueba de que nuestro cuarto era infinito, la teníamos en el huevo de cristal que estaba en la ventana y que reflejaba fielmente a nuestro cuarto. Era éste un huevo incoloro y transparente, grande como un huevo de avestruz que se dedicaba todas las mañanas a reproducir el paisaje al revés" (141).

Los objetos, que marcan siempre el espacio y lo caracterizan, son sumamente importantes en esta novela. En Palinuro de México el entorno espacial está plenamente semantizado; las formas y objetos se articulan en una compleja estructura significativa. Es posible advertir a lo largo de la novela una corriente caracterizada por la objetivación de lo humano y la humanización de los objetos.

Por una parte, Walter afirma que el cerebro, a fin de cuentas, es una "cosa" (491); en tanto que Palinuro y Estefanía quieren tanto a su cuarto que lo consideran "un ser vivo" (121). En ese espacio asistimos a pasajes insólitos que nos ponen nuevamente en la vía surrealista, tal como aquel en que "los huevos fritos se desprendieron de los sartenes y navegaron por el aire como estrellas en explosión" (120). Palinuro y Estefanía no sólo reconocen vitalidad en los objetos que forman parte de su vida, "la reconciliación con ellos fue inmaculada y absoluta" (149); y más aún, las cosas terminan por imponerse ante los personajes con "su voluntad de vivir" (143).

La doble corriente de objetivación-humanización que cruza el texto entronca con aquella ruptura epistemológica que se percibe a partir del romanticismo alemán, y refiere a la crisis que comienza a manifestarse dentro de la noción cartesiana del "yo": "Entre los románticos más lúcidos se abrirá la grieta que irá erosionando lentamente el edificio, preparando la labor para el derrumbe surrealista."22

El hombre mutilado en su yo, que la pintura surrealista captó en las imágenes de maniquíes y robots en los cuales se expresa violentamente la objetualización de lo humano, aparece también en Palinuro de México. El debilitamiento del "yo", la mecanización y la mutilación de la identi-

${ }^{22}$ Sánchez Vidal, art. cit., p. 50. 


\section{Lilia García Peña}

dad son tres grandes líneas que cruzan la novela, un poco heredando y un poco compartiendo la problemática surrealista desde la sensibilidad y la historia de su momento particular.

El problema del desdoblamiento de Palinuro es determinante en la novela: la escisión y sustitución del "yo" parece responder a este mismo proceso de objetivación de lo humano, ya que la instancia del "doble" sugiere - como señala Freud - la posibilidad de atacar el resto del propio "yo" como si fuera un objeto susceptible de autoobservación. ${ }^{23}$ Es decir, el proceso de desdoblamiento de Palinuro produce un "espantajo" semejante, muy semejante a los maniquíes de De Chirico y los robots de Ernst.

Entre los objetos que llenan las páginas de Palinuro de México, es importante destacar la recurrencia de los espejos relacionados con la duplicación y la inversión. Palinuro y Estefanía poseen un espejo que, como hemos visto en el caso de los otros objetos, está humanizado; el espejo enferma y los primos lo llevan a pasear en un intento por devolverle el resplandor de la vida:

En cuanto la sacamos a la calle, se le iluminó la cara y se le llenó de colores y movimientos [...] y los desconocidos que se cruzaron en nuestro camino lo confundieron ( $\mathrm{y}$ la confundieron) sucesivamente con un policía, con una verdulera... (152). ${ }^{24}$

El espejo en Palinuro devuelve en su reflejo una imagen transformada y deformada de quien se mira en él; así, Palinuro, desde niño se enfrenta a través del espejo en el ropero del abuelo al "aprendizaje lento de la falsificación y del lenguaje de las inversiones" (35).

Los espejos en la novela intensifican la visualidad de los objetos y fenómenos de la cotidianidad, proyectando las imágenes desde la inversión. He aquí de nuevo, el ojo deformante palinuresco que ahora, desde las profundidades de un espejo como símbolo de captación de lo real en

${ }^{23}$ Cf. Sigmund Freud, "Lo siniestro", en Obras completas, vol. III, 1973, Madrid, Biblioteca Nueva, p. 2494 [1a. ed. en alemán 1919].

${ }^{24}$ Recuérdese que el espejo de Estefanía y Palinuro cambia de sexo según quien se mire en él. 
toda su movilidad y densidad, cuestiona el conocimiento de lo real y de uno mismo.

Además del espejo de Palinuro y del espejo del cuarto de la plaza de Santo Domingo, puede advertirse un juego especular entre las imágenes de Palinuroy sus dobles: Walter, narrador-doble, y Estefanía, en el cual cada rostro es un espejo del "otro", que cuestiona la integridad de la identidad.

En Palinuro de México, la mutabilidad de las identidades se manifiesta también a través de la máscara:

Que una cosa puede ser ella y otra cosa al mismo tiempo, o muchas cosas a la vez, no era nada nuevo para la tía Luisa. Lo que es más, sus sueños le habían enseñado que una persona puede ser otras al mismo tiempo y ninguna de ellas" (479).

La presencia de la máscara en la novela se relaciona íntimamente con el problema del doble y su naturaleza especular, ya que en los dominios del Doppelgänger, un ser cubre su rostro con una máscara para asemejar la imagen de otro, o bien, ve en otro la máscara de sí mismo.

Si bien la problemática de la máscara se manifiesta a lo largo de todo el texto, es en el penúltimo capítulo, "Palinuro en la escalera", cuando el tema se despliega con toda su fuerza y se marca su función regeneradora y renovadora.

La puesta en escena de la muerte de Palinuro a la manera de la Commedia dell' Arte, nos sitúa en un mundo visual con personajes enmascarados y disfraces de colores deslumbrantes. Nos enfrentamos a un mundo delirante de imágenes intercambiables y de seres que pasan por el tamiz de numerosas transformaciones y deformaciones ontológicas, en virtud de un intercambio alucinante de máscaras y disfraces, y del entrecruzamiento de los personajes de la novela con personajes de la Commedia; en donde incluso México y sus símbolos se visualizan: Arlequín es una piñata gorda; Colombina se disfraza de Constitución Mexicana, para ser Estefanía en otro momento; el primo Walter aparece disfrazado de Pierrot y Tartaglia de atleta olímpico. 


\section{Lilia García Peña}

En el carnaval grotesco de "Palinuro en la escalera" donde la vida y la muerte se miran y se enfrentan, se exigen para poder ser, las máscaras expresan el triunfo de la relatividad y de las sucesiones. ${ }^{25}$

Lo espacial en Palinuro de México desbordado de recuerdos hechos imágenes, de máscaras, espejos e infinidad de objetos no termina donde empieza el ser humano, no sólo acoge los cuerpos sino que los invade: el cuerpo humano es espacio, espacio que se recorre centímetro a centímetro: "ella me besaba entonces treinta de mis cuarenta milímetros de labios" (122).

En la novela, se abre el deseo y la posibilidad de que el cuerpo sea imagen armoniosa del universo, "algún día, como lo ha prometido Schelling" (21); el universo ha impreso en el hombre su reflejo, y por ello conocer es descender en el espacio de sí mismo.

El ojo de Palinuro se sumerge, así, en sí mismo. Lanza al mundo, desde la interioridad del ser, una mirada poderosa que recorre las vías expresivas de la deformación y la mutación, para ir más allá de la verdad aparente de las cosas. Una mirada que surge desde el horror y la angustia de la conciencia de nuestros límites, pero que se alza o se precipita para buscar posibles cauces de liberación. 